\title{
O ESTADO E AS POLÍTICAS DE NACIONALIZAÇÃO DA INFÂNCIA NAS ESCOLAS ÉTNICAS DO PARANÁ
}

\author{
Valquiria Elita Renk ${ }^{1}$ \\ Pontifícia Universidade Católica do Paraná - PUCPR
}

\section{RESUMO}

No Paraná, até 1938, as escolas étnicas existiam a margem do Estado, com uma organização muito específica, cujos conteúdos escolares eram ministrados na língua materna do grupo, assim, como também a história, a geografia. Adotavam livros escolares na língua de origem do grupo e muitos alunos desconheciam ou poucos conheciam da língua portuguesa, apesar de serem brasileiros. Nesta pesquisa objetiva-se analisa o processo de nacionalização destas escolas e também os processos de resistência que estes grupos étnicos apresentaram às medidas implementadas pelo Estado para nacionalizar a infância. As fontes de pesquisa são os documentos oficiais, como a legislação educacional, os Relatórios e Mensagens de Governo, os arquivos particulares das instituições de ensino, também as entrevistas e depoimentos daqueles que eram alunos destas escolas em 1938, e vivenciaram a nacionalização compulsória. As fontes possibilitam o cotejamento das informações e analisar o processo de nacionalização destas escolas. Através da análise histórica será possível entender a importância da manutenção da cultura étnica para as escolas e do ensino da língua nacional, para o Estado. Desde 1909 até 1938, a legislação educacional obrigava o ensino em português, criava formas de homogeneização do ensino, para integrar estes alunos á cultura nacional, simultaneamente as escolas étnicas organizavam formas de resistência para manter a cultura. Apesar dos mecanismos de controle do Estado sobre os professores e a organização escolar, a nacionalização só se efetivou em 1938, com o fechamento das escolas étnicas.

Palavras chave: políticas de educação; escolas étnicas; nacionalização

\section{THE STATE AND THE POLICIES OF CHILDHOOD'S NATIONALIZATION IN ETHNIC SCHOOLS OF PARANÁ}

\section{ABSTRACT}

In Parana, up to 1938, the ethnic schools existed outside the State, with a very specific form of organization, whose school contents were taught in the students' mother tongue, as well as history, geography. They used to adopt textbooks in the students' native language and many of them did not know or knew very little of the Portuguese language, despite being Brazilian. This research aims to analyze the nationalization process of these schools and also the processes of resistance that these ethnic groups presented to the measures implemented by the State in order to nationalize childhood. The research sources are official documents, such as the educational legislation, Government Reports and Messages, private files from education institutions, and also interviews and testimonials from those who were students in these schools in 1938, and experienced the compulsory nationalization. The sources enable to compare the information and to analyze the nationalization process of these schools. Through the historical analysis it will be possible to understand the importance of maintaining the ethnic culture for the schools and for teaching the national language for the State. From 1909 to 1938, the education legislation required teaching in Portuguese, creating forms of education homogenization, to include these students into the national culture, as new forms of resistance were created by the ethnic schools to maintain the culture. Notwithstanding the control mechanisms by the State over teachers and school organization, nationalization only occurred in 1938, with the closing of the ethnic schools. Keywords: ethnic schools, policies of education, nationalization 


\section{Introdução}

O presente artigo tem como tema principal as políticas de nacionalização da infância, no Paraná, através da escola. O Paraná que recebeu milhares de imigrantes no século XIX e início do século XX, sendo os eslavos (poloneses e ucranianos) os grupos mais expressivos. $\mathrm{O}$ recorte temporal deste artigo situa-se nas primeiras décadas do século $\mathrm{XX}$ quando se intensificaram as políticas de nacionalização das escolas étnicas ou escolas de imigrantes. Objetiva-se analisar como as escolas étnicas foram importantes na manutenção da identidade cultural, juntamente com as famílias, as associações e as comunidades. Será analisada também a importância da língua materna do grupo étnico para a coesão cultural e a importância da língua portuguesa para o Estado, como elemento essencial da nacionalização da infância.

As fontes da pesquisa empírica traduzem diversas falas. As falas oficiais são representadas pelos documentos oficiais como os Relatórios de Governo, a legislação escolar, as correspondências de Governo; as falas das instituições de ensino, que eram as escolas étnicas que permitiram pesquisar nos arquivos, nos livros didáticos, cadernos de alunos, livros de chamada, diários de professores e as falas dos ex-alunos das escolas étnicas, com os depoimentos e entrevistas relatando a experiência da nacionalização compulsória em 1938. Os depoentes são identificados com as letras iniciais dos seus nomes e suas falas revelam os constrangimentos vividos pelo desconhecimento da língua nacional. Suas histórias de vida são reveladoras de como se sentiram estrangeiros, ao aprender e falar a língua nacional apenas ao ingressar na escola. A contextualização dos documentos revela diferentes olhares sobre a legislação educacional, as medidas adotadas pelo Estado para homogeneizar os saberes escolares, a organização pedagógica das escolas étnicas e o processo de resistência ante estas medidas. Possibilita inferir como os filhos dos imigrantes sentiam-se estrangeiros no Brasil, pelo pertencimento étnico e desconhecimento da língua nacional.

O Brasil recebeu aproximadamente cinco milhões de imigrantes, desde o século XIX até meados do século XX, sendo o maior número os europeus, entre eles alemães, italianos, poloneses, ucranianos e russos. Foram instalados em colônias étnicas organizadas pelo Estado para ocupar o território e produção agrícola. Entre as primeiras construções nas colônias estavam à igreja e a escola. As escolas étnicas eram construídas e mantidas pelas comunidades e em poucas colônias havia escolas públicas. O número de escolas étnicas no Brasil era bastante expressivo. Kreutz (2000) Ando (1976) indicam que havia 1.579 escolas étnicas alemãs, 396 italianas, 349 polonesas e 178 japonesas. No Paraná havia mais de 220 escolas étnicas polonesas e ucranianas e ainda as das outras etnias. (RENK, 2009)

A organização social das colônias girava em torno da igreja, escola, sociedade cultural e cemitério. Também produziam e divulgavam seus jornais em língua estrangeira, tinham suas sociedades que eram espaços de sociabilidades e também podia ser espaço escolar, as sociedades-escolas. Nas colônias pouco ou nada se falava em língua nacional. Os filhos dos imigrantes tinham como língua materna a língua estrangeira, mesmo nascidos no Brasil, não se percebiam como brasileiros. Muitos desconheciam a língua nacional até ingressarem na escola. A língua nacional era uma língua estrangeira e eles não se consideravam como brasileiros, não falavam o 'brasileiro' e até mesmo os registros escolares não lhes atribuíam a nacionalidade brasileira, eram 'polacos ou ucranianos'. 


\section{A importância da escola étnica nas colônias de imigração}

Nas colônias de imigrantes, a escola era um elemento fundamental, para que os filhos tivessem uma vida melhor que a dos pais, e também para diferenciar-se dos 'brasileiros'. Garantir a escolaridade dos filhos era um dos primeiros objetivos dos imigrantes. Diante da ausência ou pouca quantidade de escolas públicas, os imigrantes construíam e mantinham suas escolas, independentes do Estado. As escolas étnicas não se constituíam em uma organização monolítica quanto à organização dos saberes ou das práticas pedagógicas, pois eram organizadas pelas comunidades para atender suas necessidades. Elas tinham uma organização pedagógica própria que as diferenciava das escolas públicas. Como exemplo disso, podemos citar que, em 1937, quando da realização do Censo Escolar da Imigração Polonesa, haviam 167 escolas, sendo que 127 estavam funcionando, 32 estavam fechadas e 8 haviam sido projetadas; destas 14 ensinavam somente em português e eram as escolas subvencionadas.

Os Relatórios de Governo registraram na década de 1920, a grande quantidade de escolas étnicas nas áreas de imigração.

De um lado e de outro dessas Linhas, de distância em distância, se destacam as casas dos colonos, edificadas numa área de terreno que lhes foi ofertada pelo Governo. Bem poucos brasileiros habitam estes lugares; os colonos são todos estrangeiros, principalmente poloneses e rutenos. Em todas essas Linhas existem escolas públicas e particulares, localizadas quase sempre nas encruzilhadas. (RELATÓRIO DE GOVERNO, 1923, p. $55-56)$

O espanto (ou admiração) do Inspetor demonstra que na maioria das colônias de imigrantes, no Paraná, havia uma escola. È paradoxal que o Inspetor não descreve a ausência de escolas públicas nas áreas de imigração.

Havia diferentes formas de organização das escolas étnicas, mas, tinham elementos comuns, como o ensino na língua materna do grupo ou bilíngue (língua estrangeira e portuguesa) e adoção de material didático (livros) em língua estrangeira. A seguir podem-se conhecer diferentes formas de organização das escolas étnicas no Paraná:

- As escolas étnicas laicas, ou sociedades escolas, que eram as de iniciativa das comunidades que as construíam, compravam o mobiliário, pagavam o professor e organizavam suas práticas pedagógicas. Quando não havia o controle estatal, não seguiam os currículos preconizados pelo Estado, só passaram a fazê-lo após as imposições legais e jurídicas. Foram as primeiras formas de organização escolar nas colônias étnicas e os professores eram membros da comunidade com ou sem formação. Eram escolas privadas e se mantinham com o pagamento das mensalidades. Muitas vezes tinham uma estrutura pedagógica e didática bastante precária e ocupavam o mesmo espaço das associações étnicas. Por vezes também este espaço era a moradia do professor, a escola e a associação cultural.

- As escolas étnicas religiosas, dirigidas pelas Congregações religiosas vindas da Europa para atender esta demanda. As comunidades solicitavam sua vinda e a Igreja atendia para exercerem a função escolar. Tinham uma estrutura pedagógica e física mais organizada, tanto que muitas existem há mais de cem anos. Funcionavam como internato e externato, os professores eram os religiosos e as religiosas, que também ministravam o ensino religioso às crianças. Algumas congregações como a dos Vicentinos tinham gráfica própria e publicavam os livros escolares (bilíngues ou em língua estrangeira) e também os 
jornais étnicos. Nestas escolas os alunos pagavam mensalidades. Muitos religiosos eram líderes comunitários.

- As escolas étnicas subvencionadas, que eram aquelas onde o grupo étnico construía a escola e o governo contribuía com o pagamento do professor, existiram a partir de 1918. Nestas escolas havia a exigência de um número mínimo de 20 alunos com o ensino em língua portuguesa. Nem sempre isto ocorria, pois os grupos étnicos não as consideravam como escolas públicas e sim como escolas étnicas.

Algumas escolas étnicas se constituíam de apenas uma sala improvisada na casa do professor, ou na associação cultural (sociedade escola), outras eram mais organizadas com uma sede própria (principalmente as das congregações religiosas) e algumas tinham o primário e ginásio.

Após o término da Primeira Guerra Mundial, quando os clamores populares passaram a reivindicar a nacionalização destas escolas, o Estado passou a intervir de forma mais contundente. Até os anos de 1920, as escolas étnicas tinham a liberdade de organizar sua rotina pedagógica, pois o Estado pouco intervinha. Foram criadas medidas de controle da organização e dos saberes pedagógicos ensinados nestas escolas, como a obrigatoriedade do ensino em língua portuguesa, a adoção dos livros didáticos prescritos, respeitar as datas cívicas nacionais e cantar o hino nacional brasileiro. Além disso, as medidas de nacionalização se realizavam através das escolas, dificultando a celebração das datas da memória cívica do grupo étnico e obrigando professores e alunos a celebrar as datas do calendário cívico brasileiro. Estas medidas foram insuficientes, pois as escolas respeitavam a legislação, mas, encontravam maneiras de burlar a legislação, com a adoção do ensino bilíngue, aulas em horário integral, com um turno em português e outro na língua de origem do grupo.

Aos imigrantes interessava uma escola diferenciada das escolas públicas, que ensinasse a língua, a história, a geografia, as cantigas e a cultura de origem do grupo. Em muitas comunidades do interior não havia escolas públicas, mas, nas cidades maiores, como Curitiba, Ponta Grossa e outras, havia escolas públicas, que não eram frequentadas pelos filhos dos imigrantes. A escola étnica para manter a identidade cultural, ensinava na língua materna do grupo. Até os nomes destas escolas eram em língua estrangeira, como Deutsche Schule (Escola Alemã), Knaben Schule (Escola de Rapazes), San Stanislau, Nicolau Copérnico, Tadeu Koschiusko, e outros. A escolaridade era um elemento de diferenciação entre 'estrangeiros' e 'brasileiros', visto que a maioria da população brasileira era analfabeta, e nas colônias étnicas quase todos eram escolarizados. Para as famílias de imigrantes, os filhos deveriam estudar numa escola étnica, para aprender o legado cultural do grupo. "Nós éramos descendentes de poloneses, então queriam que nós aprendêssemos o polonês" (H.K.). Ainda afirma que o ensino era bilíngue, no horário da manhã aprendiam em polonês sobre a Polônia e no horário da tarde em "brasileiro" as lições sobre o Brasil.

Castells (2000) considera que a identidade é um processo coletivo de construção de significados por meio da história, da geografia, das instituições e da memória coletiva. Apresenta os conceitos de identidade legitimadora e identidade de resistência, analisando as tensões entre o Estado e os grupos sociais que se traduzem nas ações de imposição e resistência cultural.

Para os descendentes de imigrantes, a língua materna era elemento fundamental na manutenção da identidade étnica e a língua portuguesa necessária na comunicação com os 'nacionais. ' Stuart Hall (2003) e Cunha (1986) consideram que a língua materna é fundamental da manutenção da identidade étnica e a identidade cultural é importante na coesão do grupo. A permanência da identidade étnica e os esforços destes grupos de imigrantes na sua manutenção nos levam a dialogar com Frederik Barth (1986) e Poutignat 
e Streiff-Fenart (1998) na definição de grupo étnico e entendimento da emergência da etnicidade nos contatos entre os grupos étnicos. Portanto a identidade étnica contrastiva entre 'nós' e 'eles' pode ser entendida diante de um sistema de identidades contrastivas entre 'brasileiros' e 'imigrantes' ou estrangeiros.

A partir da década de 1920, constataram-se no Paraná dois movimentos:

a) um do Estado para a formação do cidadão nacional através da legislação escolar, imposição de calendário escolar, adoção de conteúdos escolares únicos, material didático único e do ensino da língua portuguesa, de história e geografia do Brasil, educação moral e cívica, educação física e participação das atividades cívicas como os desfiles escolares, objetivando a homogeneização dos saberes escolares.

b) outro das associações étnicas, congregações religiosas e dos consulados que passaram a buscar inúmeras alternativas para a manutenção da identidade étnica através da escola, como a produção de material didático em língua estrangeira, cursos para os professores, ensino bilíngue que formavam uma resistência às medidas legais.

O Estado, através da Inspetoria de Ensino, criou uma forma de fiscalização das escolas. Produziu vários formulários a serem preenchidos pelos professores e também as visitas dos Inspetores às escolas étnicas. Percebe-se então que, a cada legislação escolar que afirmava e reafirmava a necessidade do ensino em língua nacional, as escolas étnicas buscavam alternativas para cumprir a legislação, mas, manter uma escola diferenciada das escolas públicas.

Desde 1919, a Inspetoria do Ensino no Paraná fiscalizava as escolas do Paraná. Esta estava subdividida em Subinspetorias que fiscalizavam as escolas, produziam relatórios e indicavam providências a serem tomadas. As escolas eram minuciosamente inspecionadas, desde o mobiliário, matrículas, material didático, higiene, asseio, conteúdos escolares e também se o professor ensinava a língua nacional. Em muitos relatos, o Subinspetor informa que o 'professor era um bom agricultor' ou 'o professor fala muito mal o português'. A inspeção escolar foi um mecanismo de vigilância, detalhamento e controle das atividades das escolas e dos professores. Uma forma de coação que se transformava num ato coercitivo do Estado. Os inspetores esquadrinhavam as atividades escolares, produziam relatórios detalhando as condições de funcionamento e a forma de trabalho de cada professor.

Ante a fiscalização da Inspetoria de Ensino, as escolas étnicas encontravam maneiras de evidenciar que estava nacionalizando a infância, mostrando o quanto estes alunos falavam liam e cantavam em língua nacional. Os 'Livros de Visitas' das escolas registravam as visitas e os pareceres dos Inspetores. Também criaram mecanismos de 'esconder' do Inspetor o que não deveria ser visto. Os alunos eram 'preparados' e os professores criavam táticas para dissimular algumas ações que demonstrassem que ainda ensinavam na língua materna de origem dos alunos.

Eu estudei no Saltinho, (..) daí a gente não podia falar ucraniano. Eu era criança, tinha seis ou sete anos, eu lembro que uma vez veio uma visita e a professora, minha tia, disse: 'guardem todos os livros em ucraniano'. (...) Todo mundo guardou o material em ucraniano e daí eles (a visita) foram fazer os exames. (I.K.) 
O relato da ex-aluna é revelador das táticas, no sentido atribuído por Certeau (1994) de fazer o Estado acreditar que a infância estava sendo nacionalizada e que os alunos tinham domínio da língua nacional.

Em 1920, o Inspetor Escolar, visitando a 'Escola Polaca da Comunidade Sagrada Família' em Curitiba registrou que assistiu às aulas e constatou que as professoras tinham aptidões necessárias para exercer o magistério e que as crianças estavam aprendendo a língua portuguesa. Nas memórias do ex-aluno, ficava a lembrança do Inspetor, como alguém não pertencente à escola e que fiscalizava tudo "'Ele não olhava os cadernos da gente, ele tinha reunião com os professores, queria saber como eles davam as aulas, os livros que eles tinham - isso na escola polonesa" (H.W).

Diante do Inspetor de Ensino, a escola étnica demonstrava que estava nacionalizando a infância. Mesmo que em sala de aula os alunos aprendessem falar a língua nacional, no recreio não havia controle e então misturavam as duas línguas:

A gente falava, brincava em ucraniano. Em português, a gente cantava as canções de roda, ás vezes misturava. Agora, em Ivaí, a gente brincava mais em ucraniano ou mesmo as cantava as canções próprias que a gente cantava na época de Páscoa (IK)

Quem haveria de controlar o que se cantava no recreio?

\section{Revisitando os Códigos de Ensino para entender o processo de nacionalização}

Em princípio, é importante revisitar a legislação educacional das primeiras décadas do século XX para melhor entender as políticas educacionais e em especial as suas intenções de nacionalização das escolas de imigrantes.

Para entender a nacionalização como processo, torna-se necessário entender os Códigos de Ensino como possíveis instrumentos para nacionalizar a infância e a juventude. Os Códigos de Ensino de 1915 e 1917, no Paraná, estabeleciam no artigo primeiro que o ensino deveria ser ministrado em língua nacional. O Código de 1917 estabelecia maior ênfase à propagação do ensino, a promoção de conferências sobre a instrução pública e aulas de língua nacional, geografia do Brasil, história da civilização e do Brasil. Essas matérias ensinariam as ideias de amor à pátria e estudos de caráter moral e cívico. Esta legislação estava em consonância com as pregações nacionalistas contra a “desnacionalização da infância" nas áreas de imigração. A ênfase no fechamento das escolas étnicas encontrava voz na imprensa e também nos documentos oficiais, como está registrado no relatório do Secretário de Estado sobre o ano de 1917. Nesse ano, depois de realizadas inspeções, quatro escolas estrangeiras foram fechadas por não ensinarem em língua nacional, e Raul R. Gomes, então Delegado de Ensino do Paraná, preconizava "o banimento completo das escolas estrangeiras que timbrem em desprezar o ensino da nossa língua". (RELATÓRIO DE GIVERNO, 1918) Essa medida não foi efetivada: algumas escolas de imigrantes foram fechadas, mas a maioria permaneceu aberta, com mudanças na organização didático-pedagógica para atender à legislação sobre o ensino em língua nacional.

Nos anos de 1918 e 1919, o Governador Affonso Camargo enfatizava que aquele era o momento propício para a nacionalização de todas as escolas estrangeiras de ensino primário. Informava também que as crianças desconheciam a língua nacional, só conheciam o idioma materno. Uma das prioridades daquele governo era tornar obrigatória a cadeira de 
português em todas as escolas étnicas, o ensino de todas as matérias em língua nacional e também a abertura de escolas nos núcleos coloniais com o auxílio do governo federal (que eram as escolas subvencionadas). A subvenção às escolas efetivou-se em 96 escolas étnicas, mas, não o ensino em língua nacional.

O Governo do Estado, em 3 de abril de 1918, atendendo às determinações federais sobre a obrigatoriedade do ensino em língua nacional, aprovou a Lei 1.775, estabelecendo que, a partir daquela data, era necessária a autorização governamental para abrir uma escola particular. Esse dado torna-se significativo na medida em que haveria o controle estatal sobre abertura e condições de funcionamento das novas escolas. Nesse sentido, houve reforço das medidas de controle e funcionamento das escolas étnicas, por meio do Decreto 13.014 (4 maio 1918), mais uma vez determinando que o ensino nas escolas do Paraná deveria ser ministrado em língua nacional. Estas medidas se mostraram pouco eficazes, pois em grande maioria as escolas étnicas continuaram ministrando o ensino em língua estrangeira.

No ano de 1920, no Paraná, a política de nacionalização das escolas ganhava mais importância na legislação. A Lei 2005/1920 estabelecia no seu artigo 1. ${ }^{\circ}$ que as escolas particulares estrangeiras eram obrigadas a ensinar a língua portuguesa e história do Brasil e geografia do Brasil em língua vernácula. $\mathrm{O}$ artigo $3 .^{\circ}$ estabelecia que as escolas estrangeiras pudessem solicitar ao governo a nomeação de professor para essas matérias, sem ônus. As fontes não permitem identificar em que medida essas instruções legais foram implementadas ou mesmo quantas e quais escolas étnicas solicitaram professores para ministrar tais aulas.

A legislação escolar intensificava as atividades cívicas e patrióticas nas escolas. A comemoração das datas cívicas nacionais tornou-se obrigatórias pelo Decreto 19.488 de 15 dez. de 1930; pela Lei 259 de $1^{\circ}$. De outubro de 1936 e também pelo Decreto 7.807 e 3.546 /1941. (RENK, 2009, p.163). Por meio desta legislação o Hino nacional deveria ser ensinado e cantado diariamente em todas as escolas. Portanto as demonstrações cívicas faziam parte da obrigação pedagógica dos professores e deveria ser ensinada, repetida e internalizada pelos alunos.

Desde a primeira década do século XX, o Estado buscava a homogeneização dos saberes com a adoção uma matriz curricular única para os grupos escolares, desde 1914 e para as escolas isoladas, a partir de 1920 (Portaria no. 134, da Inspetoria de Educação). Os conhecimentos a serem ensinados uniformizariam a organização dos saberes na escola, sua distribuição nas séries e possibilitariam um melhor controle e fiscalização. Aos poucos o Estado foi institucionalizando um conjunto de instrumentos e medidas de controle das escolas, como os horários, os livros didáticos, a distribuição de mapas e bandeiras do Brasil, formando uma teia de ações e burocratizando as escolas. Souza (2004) ao analisar a escola primária paulista conclui que os hinos, cantos, canções populares foram se transformando em canções de escola e submetidas as prescrições didático-pedagógicas.

As tentativas de uniformizar os saberes escolares para as escolas públicas e privadas do Paraná datam de 1916, com a publicação da uma lista de livros didáticos a serem adotados. Entre estes havia cartilhas, livros de poesias e formação cívicas patrióticas. A partir das prescrições legais, as escolas públicas e particulares deveriam seguir os programas oficiais de ensino, adotar os mesmos livros didáticos, respeitar e celebrar os feriados cívicos, possibilitando a homogeneização dos saberes. Além das cartilhas as aulas de educação física, canto, educação moral, trariam contribuições na formação patriótica dos alunos. Mais ainda, a participação e celebração das datas cívicas que ocorriam nos desfiles escolares, contribuiriam na formação do sentimento de pertencimento nacional. 


\title{
A socialização das crianças e a manutenção da identidade étnica
}

Muitas jovens de famílias descendentes de eslavos tiveram o primeiro contato com a Língua Portuguesa na escola. Esta era a segunda língua de muitos alunos. "Era muito difícil a língua portuguesa", relata P.K, hoje com seus 98 anos de idade, que sofreu para aprender esta língua na escola. Muitos alunos não entendiam o que era dito, não compreendiam as lições e nem o que o professor dizia. As lembranças desta experiência só podem ser relatadas por que a vivenciou

\begin{abstract}
Quando eu completei oito anos, em 1918, eu entrei para a escola pública de Mallet e foi meu primeiro contato com a língua portuguesa, pois em ucraniano eu já sabia ler e escrever, minha mãe e minha irmã mais velha me ensinou em casa o ucraniano. Eu tinha muita vontade de aprender, então minha irmã de noite me ensinava o português, eu aprendia a ler a cartilha, em língua portuguesa. (...) No final de 1919 meu pai se mudou prá União da Vitória e lá eu entrei no grupo escolar, ali tinha quatro salas e o primário era composto de quatro anos, mas em período integral, oito horas de aula. Então o professor mandava um aluno ler em voz alta e se ele lia errado, o professor corrigia que era para assimilar estas pronúncias. $\mathrm{O}$ professor ditava e os alunos escreviam e depois então ela corrigia. Era muito difícil a língua portuguesa. (P. K)
\end{abstract}

O relato anterior demonstra a dificuldade do aluno em aprender a Língua Nacional, apenas na escola, pois já era alfabetizado em outra língua. Esta situação acima relatada não era exceção e sim quase uma regra nas famílias de imigrantes. Também o estranhamento diante da língua vernácula, não entender o que o professor dizia e a denúncia da pouca familiaridade ante o sotaque.

Nas colônias étnicas, as primeiras formas de organização escolar eram bastante precárias, na ausência de professores com habilitação, os próprios colonos de organizavam e assumiam esta função. Os saberes transmitidos e ensinados eram os de interesse no grupo e remetia à pátria de origem.

\begin{abstract}
No início o programa escolar era de dois anos. As irmãs alfabetizavam, ensinavam os elementos básicos da leitura e da escrita e os rudimentos de aritmética. Os alunos vindos das colônias apresentavam inteligência rude e capacidade lenta de aprendizagem, devido ao isolamento e pouca cultura das famílias. Alguns anos depois o programa passou para quatro anos. $\mathrm{O}$ currículo então passou a ser: Língua Polonesa, Aritmética, História da polônia, Geografia Geral, Geografia da Polônia e Religião. Ensinavam ainda Canto Popular e Religioso, Educação Física, História Natural, Desenho e Religião. (SANGALI, 2007, p. 41)
\end{abstract}

Em terras brasileiras, as novas gerações de imigrantes precisavam aprender a língua portuguesa. Quando os jovens começavam a se relacionar com pessoas de fora da comunidade, principalmente 'brasileiros', aprendiam a língua nacional, repassavam este aprendizado aos irmãos menores. Fora do ambiente familiar, havia a necessidade de se expressar em língua portuguesa. Os homens pelas lidas com o comércio necessitavam se 
expressar mais em língua nacional do que as mulheres, que em sua maioria permaneciam no âmbito do lar. Assim, até hoje os sotaques são reveladores de que a língua nacional foi a segunda língua aprendida. "Em casa só falava em ucraniano, português a gente não sabia. Depois que começou a ir prá escola, os meus irmãos mais velhos, falavam entre eles e a gente escutava e foi assim, devagarzinho aprendendo." (A.N). Muitas vezes o sotaque é quase como um pedido de desculpas por não dominar a língua nacional, mas ao mesmo tempo revelador da condição de descendente de imigrante. Ainda hoje, para a geração mais velha a falta de familiaridade com a língua nacional faz com que as palavras se misturem nas duas línguas. "Não falo bem, português, tem muita coisa que a gente troca, não falo correto" (A.N).

As crianças eram socializadas nos valores culturais do grupo e as memórias dos tempos de infância ainda lembram as situações onde a língua nacional não era usa cotidianamente. "Minha mãe se fossemos falar com ela em português, ela não respondia. As outras tiveram mais sorte, as irmãs mais novas." (H. K.). Quando perguntada qual o motivo da sorte, a resposta foi "porque ela não conseguiu ensinar polonês prá elas." Certamente com a educação dos filhos mais novos, em muitas famílias já era percebida a necessidade do aprendizado e comunicação em língua nacional.

Algumas famílias (raras) faziam a opção de não ensinar a língua de origem do grupo para que os filhos aprendessem a língua nacional.

Ela (mamãe) casou com um homem polaco também, então a filha mais velha só falava em polaco em casa e quando foi prá escola ela sofreu demais, demais, porque ela não entendia o que os professores falavam. Então, mamãe terminou com o polaco em casa. Só se falava o português. Mamãe teve seis filhas e daí ensinou o português para as outras filhas. (P.S)

A transmissão da cultura para as gerações mais novas acontecia no seio da família, as mães e avós tiveram um papel muito importante, pois a língua é memória, é repleta de significados. Mesmo após o período de nacionalização, dificilmente as famílias abandonaram a língua materna no espaço da casa.

Eu ensinei meus filhos a falar polonês. Até os quatro, cinco anos, a primeira filha só falava em polonês, daí tinha que ensinando português pra ela ir ao jardim, no primeiro ano. Eu acho que o professor sofreu com ela, porque ela não entendia. Tanto é que ela compreende tudo, mas, não fala, fala alguma coisa (Z.S).

Esquecer a língua materna pode significar esquecer as origens. As mulheres lembram que ensinaram a língua de origem a seus filhos. Atualmente, o ensino em língua nacional, a vida urbana, fez com que alguns fossem esquecendo a língua materna. A maioria dos depoentes relatou que ensinaram a língua estrangeira como língua materna aos seus filhos. "Falavam muito bem, mas, agora estão esquecendo (...). A minha filha mais velha escreve, lê em ucraniano, muito bem". (A.N). Hoje diferente de outros tempos, a identidade étnica é quase invisível, está diluída no espaço urbano.

Nas reuniões familiares a tradição cultural do grupo era transmitida oralmente pelos mais velhos. "A gente cantava o hino polaco na casa da vovó, que morava na Campina da Siqueira, isto quando era criança, eu tinha uns oito ou nove anos e não sabia que era o hino polaco". (P.S). Pierre Nora nos diz que "a memória é a vida, sempre carregada por grupos vivos e sentido. Ela permanece (...) aberta à dialética da lembrança, esquecimento..." (1993, p. 8). 
Contar histórias, cantar as músicas, as lendas... eram formas de transmitir às crianças o legado cultural que identificava o grupo. Este legado cultural também era ensinado pela escola nas aulas ministradas em língua estrangeira, nas cantigas e nas lições de História do país de origem. Para os idosos o idioma materno era o usual, na comunidade, todos entendiam. "Tinha a minha avó que não sabia dizer nem uma ou duas palavras em brasileiro. Não falava nada." (A. N.)

Entre as memórias dos ex-alunos das escolas étnicas, destaca-se a importância da escola em ministrar os conteúdos escolares na língua pátria ou de formação bilíngue. Nos depoimentos dos ex-alunos, comemorativos aos Cem Anos do Colégio Vicentino São José de Curitiba (antiga Escola Étnica Polonesa Abranches) fica evidenciada esta importância. Quando perguntados sobre os que se lembravam da escola, dos tempos de infância, pode-se conhecer os fragmentos das memórias e a importância evidenciada ao ensino da língua materna do grupo étnico pela escola: "Aprendemos a rezar em polonês, e também Matemática e Português"; Outro afirma: "A aula começava as 8:00 h da manhã e ia até as duas da tarde; nós estudávamos Português, Língua Polonesa, História, Geografia, Aritmética, tudo em polonês" ; As datas cívicas da pátria de origem do grupo eram celebradas na escola: "No dia 03 de maio, havia a festa de Emancipação da Polônia" ; O bilinguismo marcou alguns os tempos de escola: "Tínhamos aulas em polonês e em brasileiro, e ainda lembro com saudades que antes de começar a aula cantava o Hino Nacional e o Hino à Bandeira e em seguida na sala nós rezávamos"; Aprendia sobre o Brasil, o tamanho, os rios, mas, tudo em polonês". (ARQUIVOS DO COLÉGIO VICENTINO SÃO JOSÉ DE CURITIBA, 2004).

A língua de origem era o principal elemento de manutenção da identidade étnica, era a língua falada em casa, cantada na igreja, lida nos jornais e ensinada na escola por meio dos ditados, das lições e das cartilhas. As aulas bilíngues foram muito lembradas aos ex-alunos que frequentaram estas escolas na década de 1930. Aprendiam as lições em português "a parte do Brasil e em polonês a parte da Polônia. Aprendia também os Hinos da Polônia, a História da Polônia." (H.K).

Nas escolas étnicas a língua portuguesa passou a ser ensinada por pressão governamental, através das fiscalizações e inspeções escolares. Muitos professores das escolas étnicas também não dominavam a língua portuguesa. O Decreto-lei 2.157, de 08 de abril de 1922, estabelecia que as escolas particulares tinham liberdade de ensino, desde que ensinassem em língua nacional, respeitassem os feriados nacionais, cumprissem os programas oficiais de ensino de português, história e geografia do Brasil. Além disso, cada professor precisou assinar um documento se comprometendo a cumprir o programa oficial de ensino. Ante isso, havia poucas alternativas ás escolas étnicas a não ser ministrar estas aulas. Ainda mais, os professores das escolas étnicas precisaram comprovar publicamente o domínio da língua portuguesa e fazer um teste de proficiência nesta língua. As associações culturais étnicas organizaram cursos de língua portuguesa para que os professores tivessem o domínio desta língua, ante a fiscalização escolar.

Estas medidas surtiram efeito, tanto que em 1924, o Inspetor Martinez relatava:

Há uma acentuada diferença no ensino das escolas polonesas. As religiosas esforçam-se para aprender a língua, os livros nacionais começam a ser lidos, os hinos pátrios começam a ser cantados, nossa bandeira começa a ser hasteada, os símbolos poloneses começam a ceder espaço para os brasileiros (...). Os cadernos estão escritos em português. Conversando com as crianças elas já sabem responder em português. Somente as crianças recém ingressadas ainda falam somente em polonês. (RELATÓRIO DE GOVERNO, 1924, p. 37). 
As escolas étnicas apresentavam uma face 'nacionalizada' aos inspetores de ensino. Ensaiavam os hinos nacionais, havia os cadernos para escrever somente em português, fazendo com que o Inspetor de ensino acreditasse que a infância estava sendo nacionalizada. Mas, diferente dos relatos dos ex-alunos, as escolas adotavam táticas de parecer nacionalizadas e adotavam o bilinguismo como uma forma de resistência e uma possibilidade de manter a cultura de origem.

Ao estudar as escolas ucranianas no Paraná, o padre Zinco (1960, p. 96) afirmava que as autoridades já haviam entendido que não adiantaria enviar professores brasileiros para as regiões de imigração, visto que esses professores não dominavam a língua materna dos alunos, que consequentemente nada entenderiam. Esse autor ainda aponta quatro casos de escolas ucranianas que foram repreendidas pelos inspetores por não ensinarem a língua nacional. Uma professora religiosa deixou o seguinte registro em suas memórias: "o governo paranaense pouco se interessava ou se ocupava das escolas ucranianas, e quando voltava a atenção a elas, era em um tom extremista" (ZINCO, 1960, p. 97). Mas se o governo do Paraná não adotasse políticas de nacionalização das escolas, quando os alunos das escolas étnicas seriam incorporados à comunidade nacional?

O tempo escolar, segundo Viñao Frago (1998) é um tempo institucional, pessoal, cultural e individual. No tempo escolar, o Estado criou o tempo de criação de uma memória nacional, através das festas e celebrações cívicas.

Ao tomar as datas cívicas uma atividade escolar, o Estado, fez da escola primária um instrumento de perpetuação da memória nacional. As festas escolares, diferentemente das festas do calendário social, não contrapõem o tempo livre ao tempo de trabalho, pois elas constituem tempo de atividade educativa, um tempo a aprender. (SOUZA, 1999, p. 134)

Apesar destas medidas do Estado, os alunos das escolas étnicas não foram nacionalizados. Somente, a partir de 1938, com a nacionalização compulsória e o fechamento das escolas étnicas é que a língua nacional passou a ser a única língua escolar.

\section{A nacionalização compulsória do ensino e formas de resistir à nacionalização}

O fechamento das escolas estrangeiras ocorreu em 1938, por meio do Decreto Federal 406 (4 maio 1938), ${ }^{2}$ conhecido como Lei da Nacionalização, cujo texto determinava que

[...] todo o ensino fosse em língua portuguesa, que todos os professores e diretores fossem brasileiros natos, que nenhum livro de texto, revista ou jornal circulasse em língua estrangeira nos distritos rurais e que o currículo escolar deveria ter instrução adequada em história e geografia do Brasil. Proibia o ensino de língua estrangeira a menores de 14 anos e ordenava que se desse lugar de destaque à bandeira nacional em dias festivos, rendendo-se homenagem à mesma. (BRASIL, 1938, p. 162)

Essa lei foi determinante no fechamento das escolas étnicas, pois o ensino só poderia ser ministrado em língua nacional. Portanto, a lei não impedia que as escolas funcionassem, mas elas perdiam o caráter étnico. As associações culturais que tinham função escolar tiveram de mudar seus estatutos e não poderiam mais funcionar como espaço de instrução. Os jornais e publicações passaram a ser publicados em língua nacional ou então fecharam.

Posteriormente, foram promulgados outros decretos e leis complementares a essa, como a Lei Federal 7.614 (12 dez. 1938), que no seu artigo 7. estabelecia que "a instrução 
primária será ministrada exclusivamente em português”. O material didático e os livros escolares também foram objeto de censura, com o Decreto 1.006 (10 dez. 1939), assinado pelo presidente da Getúlio Vargas. Todos os materiais didáticos produzidos deveriam ter a aprovação do governo e seguir a linha política do Estado Novo.

O Exército Brasileiro também se empenhou em nacionalizar os jovens nas áreas de imigração: quem não soubesse falar o português fluentemente deveria ficar dois anos prestando o serviço militar, e aqueles que lessem e escrevessem em português ficariam um ano e meio. ${ }^{3}$

O espaço escolar foi respeitado quase como um espaço sagrado, no qual a lei de nacionalização foi respeitada e obedecida. Durante a produção das fontes orais, ouviu-se muitas vezes que no espaço da sala de aula havia muito temor. Quando se perguntava se os professores não burlavam a lei e não ensinavam em língua estrangeira, a resposta era unânime: "Não, era proibido." No espaço escolar, a proibição foi acatada e respeitada, não sem resistências (as formas de resistências serão abordadas na parte final deste capítulo). As aulas de catequese, ministradas na língua materna do grupo, foram espaço de resistência. Eram ministradas fora do espaço escolar, fora do horário das aulas, e ensinava-se a catequese sem alarde, em um pacto entre catequistas e catequizados. As catequistas tiveram importante papel no ensino da língua e na manutenção da identidade étnica do grupo.

Os professores não ministraram mais aulas em idioma estrangeiro. $\mathrm{O}$ controle era rigoroso. Quando foi perguntado à depoente IK se os professores não burlavam essa legislação e não ensinavam em língua estrangeira, ela foi categórica: "Não durante a aula, não. Nunca foi permitido." Mas contou que a família pagava aulas particulares de língua ucraniana, "Onde a gente aprendia a ler e cantar, mas na escola não." (I K) E aprender primeiro a língua estrangeira, e depois a língua nacional, também deixou o sotaque: "a gente aprendia muito fácil, a pronúncia não saía tão bem" (IK).

O Decreto 406 obrigava o ensino em língua nacional e essa era uma situação delicada: como fazer os alunos compreenderem em língua nacional, que lhes era pouco familiar, ou até desconhecida? Como ministrar as lições em uma situação assim? Era um grande desafio. Mas os professores precisavam encontrar mecanismos para ensinar aos alunos em língua nacional, mesmo quando fossem pouco compreendidos.

Muitos professores das escolas étnicas se utilizavam de táticas como a "tradução" das lições da língua vernácula para a língua estrangeira, para bem haver um processo de compreensão (CERTEAU, 1994). As práticas cotidianas, como falar e ler, são parte das maneiras de fazer, sendo uma vitória do "fraco" sobre o "forte". Aqui não se pode falar em vitória, mas em uma possibilidade de inteligibilidade em sala de aula, até porque o Decreto 406, sobre a nacionalização não chegou a ser revogado. A professora que lecionou no Colégio Vicentino, em Curitiba, entre 1945 e 1949, permite-nos conhecer a tarefa de como alfabetizar uma criança brasileira que desconhecia a língua nacional:

No meu tempo já tinha terminado o ensino em polonês, mas a gente ainda conversava algumas palavras em polonês na sala de aula devido que havia muitas crianças polonesas que não entendiam o que a gente falava. Não falava português e não entendiam o que a gente estava falando. Realmente, na primeira série principalmente, era tão difícil porque às vezes tinha que fazer a explicação em português e em polonês. Fazer a explicação de matemática em polonês, porque eles não entendiam. Então eu falava em polonês para eles e eles me entendiam, porque às vezes a criança ficava me olhando assim, não sabia nada do que falei. [...] mas os poloneses eram mais firmados, mais seguros na língua, aqui era uma colônia polonesa. 


\section{(ARQUIVOS DO COLÉGIO VICENTINO SÃO JOSÉ DE CURITIBA, 2008)}

O relato da então professora demonstra que não era uma tarefa fácil nacionalizar as crianças brasileiras com ascendência eslava sete anos após a nacionalização compulsória. Alguns alunos da primeira série passavam a ter familiaridade e conhecer a língua nacional na escola, para aqueles pequenos alunos, a língua nacional era uma língua nova, desconhecida, e eles precisavam primeiramente compreendê-la para depois serem alfabetizados. Os professores tornaram-se intermediários de uma situação de ensino em que era necessário usar duas línguas (a nacional por força da lei e a estrangeira para ser entendidos) para que fossem minimamente compreendidos. Para os alunos que não falavam o idioma nacional em casa, foi difícil iniciar a vida escolar após a nacionalização. As crianças literalmente aprendiam a falar em português na escola:

Era ainda uma mistura, porque as crianças em casa falavam polonês, elas foram aprendendo algumas palavras em português na escola. Era obrigatório o português. Elas não entendiam português. Então as irmãs tinham que falar e traduzir tinham que explicar em polonês daí eles entendiam. Então tinham que decorar as palavras. A irmã passava a lição em português e as crianças repetiam até decorar, não entendiam o que estavam dizendo, mas, tinham decorado. Em casa os pais falavam polonês, né. (PL)

Os relatos trazem à tona uma situação vivenciada em silêncio, na sala de aula, que não podia ser tornada pública, diante do temor e da repressão. Não poder expressar-se na língua materna foi uma violência imposta àquelas crianças. O Estado reivindica a si o monopólio do uso legítimo da violência física e simbólica em um determinado território e sobre sua população (BORDIEU, 1996). Sem entender a língua portuguesa, as crianças repetiam as palavras, até internalizá-las. A memória acionada traz à tona a cumplicidade e as táticas construídas entre professor e aluno, no ato de ensinar, na tradução das lições para a língua nacional.

A ruptura do silêncio ocorre 70 anos depois, quando é feita a releitura do ocorrido. Esse processo foi tão traumático que algumas famílias decidiram não ensinar mais o idioma materno para os filhos, renegar a língua estrangeira diante dos filhos e falar somente a língua portuguesa em casa. O idioma mantinha um papel de "unificação nacional, ora servindo para aglutinar as populações, ora sendo imposto em nome da unificação de uma população em um território nacional" (SOUZA, 1990, p. 48). No Brasil, durante o processo de nacionalização, o idioma adquiriu o sentido de unificação nacional. No entendimento do Estado, era preciso acabar com as diferenças étnicas e regionais, ser uma nação com uma cultura nacional, única.

Nas escolas, a proibição do ensino em língua estrangeira foi rigorosa, mas como o governo poderia controlar no interior das famílias? Nos espaços públicos, a vigilância policial e dos "outros" era rigorosa, mas haveria como o governo vigiar no íntimo do lar? As crianças foram ensinadas a ter certos cuidados, afinal era a época da guerra: "Não era medo, mas, sempre ouvíamos falar dos cuidados que precisavam ter, pois era guerra, cuidar para não criticar e não falar o ucraniano." (IK) Era preciso ter muito cuidado, principalmente com estranhos, pois havia o risco de ser delatado às autoridades.

Durante o Estado Novo, os professores estavam temerosos e sabiam que, se não ensinassem os alunos em língua nacional, poderiam ser presos. Mas muitos alunos insistiam que se ensinasse a língua e a cultura do grupo na escola, embora no espaço escolar isso não acontecesse mais. 
As freiras tinham medo de cantar em polonês, então nós provocávamos, às vezes. Nós dizíamos "Vamos cantar" e elas diziam "Não pode, nós vamos ser presas". Nós dizíamos, "Se vocês forem presas, nós iremos junto com vocês". Mas nunca teve fiscalização disso na escola. (PL)

Sabendo que o espaço da escola era vigiado, professores buscaram alternativas fora do espaço escolar para ensinar a língua materna aos alunos, nas escolas religiosas:

Não, durante a aula não se podia falar ucraniano. A gente tinha as aulas de catequese em ucraniano, onde a gente aprendia a ler e cantar, mas na escola não. [...] Tinha alguns livros, mas escondidos. A minha primeira professora, a minha tia, era muito dedicada, ela não misturava as lições. Na escola, só português e depois da aula, a catequese em ucraniano. (IK)

Para a sobrevivência da cultura materna, foram criadas táticas que escapavam do controle oficial. As aulas de catequese eram um momento de continuar a aprender a língua de origem do grupo, com a cumplicidade das professoras e catequistas:

Depois do horário da aula ela ensinava em ucraniano. O pessoal trazia os caderninhos de ucraniano e depois da aula eles ficavam mais meia hora, por aí, e daí ela ensinava a catequese em ucraniano. (IK)

Fora da escola, nos quintais, galinheiros, campos ou aula de catequese, garantia-se que as crianças não esquecessem a língua materna. AN relata que nos tempos de nacionalização não se podia falar nem rezar em ucraniano. Na Colônia Marcelino, as religiosas não descuidaram de ensinar a língua ucraniana, a pedido dos pais, mas fora do espaço escolar:

As freiras começaram a ensinar porque daí os pais diziam "Como é que nossos filhos não vão saber ucraniano? Então daí a freira dava aula pra nós assim de manhã, escondido num galinheiro, num ranchinho que tinha no quintal. Então nós estudávamos lá. Assim, nós ia das oito às dez, mais ou menos, ficávamos fechadinhos e a freira ensinava ucraniano pra nós. Daí, quando já vinham as outras crianças pra escola, a gente tinha que sair e ficar brincando juntos com eles, pra ninguém desconfiar que estávamos estudando ucraniano. Não podia falar ucraniano na escola. (AN)

Havia espaços no mundo rural que não foi objeto de vigilância pelo do Estado. Um desses espaços era o galinheiro, onde jamais um fiscal ou inspetor de ensino iria verificar a prática ilegal da língua ucraniana. Situações como essa eram corriqueiras: um galinheiro se tornar espaço de resistência para o aprendizado da língua.

Neste texto, valemo-nos dos estudos de Michel Certeau (1994), principalmente as maneiras de fazer, as astúcias, que são as práticas pelas quais os grupos étnicos conseguiram encontrar formas de burlar a legislação e manter a identidade étnica. De fato, as comunidades étnicas encontraram formas de fazer que permitissem manter a identidade étnica do grupo, ensinar em língua nacional e não sofrer as sanções prescritas na legislação.

Muitas escolas das comunidades étnicas eram fiscalizadas para se comprovar se os alunos já estavam se nacionalizando. Entre as possibilidades de fiscalização estava o envio de um inspetor à escola, solicitando que os alunos cantassem o Hino Nacional, ou então participando dos exames finais. Nessas ocasiões, o inspetor poderia averiguar se os alunos já dominavam o idioma nacional.

O senhor EK se lembra de quando estudava em uma classe multisseriada em Ivaí. No exame final, os alunos tiveram dificuldade para se expressar em português. O Inspetor fazia 
as perguntas em língua nacional, os alunos não compreendiam e então o professor precisava traduzir a sua fala aos alunos e as respostas dos alunos ao inspetor. Nessa ocasião, foi solicitado aos alunos que cantassem o Hino Nacional. Eles começaram a cantar, mas não sabiam toda a letra e houve constrangimento para.

Em outra escola, em Prudentópolis, um senhor, descendente de ucranianos, relata a visita de um inspetor escolar para aplicar os exames finais. Ele perguntou aos alunos se sabiam cantar o Hino Nacional. Eles responderam afirmativamente e ele solicitou que o fizessem: "Então cantem." O que ouviu foi o Hino Ucraniano. "Só sabia o ucraniano... O inspetor ficou com aquela cara, 'Muito bonito, hein?'. 'Hino Nacional bonito o de vocês'." (GUÉRIOS, 2007, p. 203-05) A memorização das lições, a repetição á exaustão até que os alunos soubessem minimamente se expressar em língua nacional, foram medidas adotadas pelas escolas étnicas.

A professora Cecília Semchechem, de Prudentópolis, levava os alunos para o campo diariamente e ali ensinava ucraniano, a pedido dos pais, que queriam seus filhos alfabetizados nessa língua. A sua forma de fazer era tirar os alunos da sala de aula, iam ao campo, como se fossem fazer um recreio, e então se ensinava em língua ucraniana, longe dos olhos da inspeção e sem levantar suspeita (GUERIOS, 2007). No espaço escolar, respeitava-se a legislação, mas, fora da sala de aula, quem iria suspeitar que a atividade desenvolvida no campo fosse realizada em língua ucraniana?

A mesma professora também relatou que nos dias de chuva levava seus alunos a um paiol nas proximidades da escola e lá ministrava aulas de religião em língua ucraniana. Os alunos "brasileiros" não permaneciam na escola, pois a eles não interessava a aula em língua ucraniana. Essa preparação para a primeira comunhão era atendendo a um pedido dos pais.

\section{Para concluir}

Nas primeiras décadas do século $\mathrm{XX}$, o Estado fez inúmeros esforços para nacionalizar os filhos dos imigrantes no Paraná, através das escolas. Mesmo a homogeneização dos conteúdos, dos livros didáticos, dos horários, as aulas de história, geografia do Brasil, educação moral e cívica e educação física, não foram suficientes para que estes alunos se sentissem brasileiros. Sentiam-se estrangeiros no sentido étnico, mas, não negavam a cidadania brasileira.

Ante as medidas estatais de nacionalização do ensino e formar o sentimento de pertencimento á nação, as escolas étnicas viam se obrigadas a cumprir a legislação, mas, ao mesmo tempo criaram formas de fazer para manter a identidade cultural, o que as diferenciava das escolas públicas. Este processo foi se construindo durante as décadas de 1910 até a nacionalização compulsória em 1938.

Até 1938, as instituições étnicas publicavam seus livros didáticos em língua estrangeira e eram adotados pelas escolas étnicas. $O$ aprendizado bilíngue também possibilitou a manutenção da identidade étnica por mais um tempo. Após o fechamento das escolas étnicas em 1938, muitos alunos foram enviados às escolas públicas e relatam que lá não eram reconhecidos como brasileiros e sim como 'polacos'. As outras crianças perguntavam: 'o que esta polacada está fazendo em nossa escola?'

As fontes documentais e também as entrevistas permitem entender este processo de consolidação das políticas públicas e de resistências. Muitos entrevistados, hoje senhores e senhoras com mais de 80 anos, ainda se emocionaram ao lembrar-se dos tempos escolares. Para outros o processo de nacionalização foi muito traumático e ainda recordavam das medidas adotadas pelas famílias para não adotar mais a língua do grupo como primeira língua. Muitos ex-alunos lembravam-se dos constrangimentos sofridos ao chegar a uma 
escola pública ou logo após á nacionalização e sentir-se um estrangeiro por não entender a língua portuguesa. Neste sentido, as fontes orais contribuíram sobremaneira para entender o processo de resistências à nacionalização.

A pesquisa também mostrou que há muito que estudar sobre as escolas étnicas, muitos documentos foram perdidos para sempre, ante a política do Estado Novo e da mesma forma os livros das bibliotecas das escolas étnicas estão desaparecidos. A política repressora do Estado Novo processou muitos professores e escolas étnicas, fechou as associações culturais que não puderam ter a função instrutiva e desta maneira grande parte da memória documental se perdeu. No Paraná, foram fechadas 78 escolas étnicas e foram construídas somente 37 novas escolas, mas, em número suficiente para suprir a quantidade de escolas étnicas que foram fechadas. (RELATÓRIO DO GOVERNO MANOEL RIBAS, 19371942, p. 23-26)

Pode-se afirmar que uma das medidas da nacionalização foi o ensino e uso da língua nacional por todos os brasileiros, a partir de então. As escolas não mais ensinaram em língua estrangeira no espaço escolar, a legislação foi respeitada, mas, não se pode afirmar que todos foram nacionalizados.

\section{Referencias}

ANDO. Z. Estudos sócio-históricos da imigração japonesa. São Paulo: Centro de Estudos Nipo-brasileiros, 1976.

BARTH, F. Ethnic groups and bourdaries. London: GA and U, 1986.

BOURDIEU, P. Razões práticas sobre a teoria da ação. Campinas: Papirus, 1996.

CANCELLI, E. O mundo da violência. A polícia da era Vargas. Brasília: EDUNB, 1993

CASTELLS, M. O poder da identidade. São Paulo: Paz e Terra, 2000

CERTEAU, M. A invenção do cotidiano. Artes de fazer. Petrópolis: Vozes, 1994

CUNHA, M.C. Antropologia do Brasil. São Paulo: Brasiliense/EDUSP, (1986)

GUÉRIOS, R.F. Memória, Identidade e religião entre os imigrantes rutenos e seus descendentes no Paraná. 2007. 292 f.Tese (Doutorado em Antropologia Social), Museu Nacional, Universidade federal do Rio de Janeiro.

HALL, S. Da Diáspora: identidades e mediações culturais. Belo Horizonte: Ed da UFMG, 2003.

KREUTZ, L. Escolas comunitárias de imigrantes no Brasil: instâncias de coordenação e estruturas de apoio. Revista Brasileira de Educação, no. 15, p. 159-176, set/dez,2000

POUTIGNAT, P; STREIFF-FENART, J. As teorias da etnicidade. São Paulo: UNESP, 1998.

RENK, V. E. Aprendi falar português na escola! O processo de nacionalização das escolas étnicas polonesas e ucranianas no Paraná. 2009. 241f. Tese de Doutorado em Educação. Universidade Federal do Paraná

SAGALLI, A. Colégio Vicentino São José 1904-2004. Curitiba: Colégio Vicentino São José, 2007.

SOUZA, R.F. Tempos de infância, tempos de escola: a ordenação do tempo escolar no ensino primário paulista (1892-1933). In Educação e Pesquisa. V. 25, no.2 jul/dez, 1999. 
VIÑAO FRAGO, A. Tiempos escolares, tiempos sociales. Barcelona: editorial Ariel S.A, 1998.

ZINCO, B. As escolas particulares ucranianas no Brasil. Prudentópolis: Basilianos, 1960.

\section{DOCUMENTOS}

ARQUIVOS DA CONGREGAÇÃO VICENTINA DE CURITIBA, 2009.

ARQUIVOS DO COLÉGIO VICENTINO DE CURITIBA, 2008.

PARANÁ. Relatório do Secretário de Estado dos Negócios do Interior, Justiça e Instrução Pública, 1917. Curitiba: DEAP

PARANÁ. Relatórios de Governo apresentado ao Secretário Geral do Paraná, pelo Professor Cesar P. Martinez em 1920, 1921, 1923 e 1924. Curitiba: DEAP

PARANÁ. Relatório do Governo Manoel Ribas, 1937-1942. Curitiba: DEAP, 1942

PARANÁ. Decreto n. 17 de 09/01/1917. Código de Ensino. Curitiba: DEAP.

PARANÁ. Lei n. 2005 de 09/04/1920. Código do Ensino. Curitiba: DEAP

PARANÁ. Decreto lei no. 2157 de 08/04/1922. Código do Ensino. Curitiba DEAP

PARANÁ. Lei 1775 de 03/04/1918. Determina a obrigatoriedade do ensino da Língua Portuguesa. Leis de 1918. Curitiba: DEAP

BRASIL. Coleção de leis da República dos Estados Unidos do Brasil de 1930 a 1945. Curitiba: DEAP

\section{ENTREVISTAS}

I.K. Entrevista concedida á Valquiria E. Renk, em meio digital, em 13/03/2008, em Curitiba.

E.C. Entrevista concedida á Valquiria E. Renk, em meio digital, em 07/03/2008, em Curitiba.

A.N. Entrevista concedida á Valquiria E. Renk, em meio digital, em 14/02/2008, em Curitiba.

H.S. Entrevista concedida á Valquiria E. Renk, em meio digital, em 17/04/2008, em Curitiba.

S.W. Entrevista concedida á Valquiria E. Renk, em meio digital, em 17/04/2008, em Curitiba.

P.K. Entrevista concedida á Valquiria E. Renk, em meio digital, em 16/07/2008, em Curitiba.

P.L. Entrevista concedida á Valquiria E. Renk, em meio digital, em 08/01/2008, em Curitiba.

A.K Entrevista concedida á Valquiria E. Renk, em meio digital, em 13/03/2008, em Curitiba.

P.S Entrevista concedida á Valquiria E. Renk, em meio digital, em 09/05/2008, em Curitiba. 
E.K. Entrevista concedida á Valquiria E. Renk, em meio digital, em 08/05/2008, em Curitiba.

C.M Entrevista concedida á Valquiria E. Renk, em meio digital, em 09/05/2008, em Curitiba.

M.V. Entrevista concedida á Valquiria E. Renk, em meio digital, em 30/01/2008, em Curitiba.

\section{Notas}

${ }^{1}$ Mestre em Educação e Doutora em Educação, Professora da PUCPR- Pontifícia Universidade Católica do Paraná -. Pesquisa sobre as escolas de imigrantes no PR, as políticas de nacionalização do Ensino nas escolas étnicas do PR, nas primeiras décadas do século XX

${ }^{2} \mathrm{O}$ que se refere aos Art. 85 a 90, que tratam especificamente do uso da língua nacional em livros, jornais e revistas.

3 O General Meira de Vasconcellos foi indicado por Vargas como responsável pela "campanha de naturalização ostensiva, para absorver as minorias brasileiras" e até setembro de 1939 já estava determinado que os serviços religiosos devessem ser em língua nacional, que nas escolas só se falasse em Português e que nos negócios não se pronunciasse língua estrangeira (CANCELLI, 1993, p. 136).

Recebido em agosto-2012

Aprovado em março-2013 